\title{
In vitro evaluation of the action of irrigating solutions associated with intracanal medications on Escherichia coli and its endotoxin in root canals
}

\author{
Lilian Eiko MAEKAWA ${ }^{1}$, Marcia Carneiro VALERA ${ }^{2}$, Luciane Dias de OLIVEIRA ${ }^{3}$, Cláudio Antonio Talge CARVALHO ${ }^{4}$, \\ Cristiane Yumi KOGA-ITO5 , Antonio Olavo Cardoso JORGE ${ }^{6}$
}

\begin{abstract}
1- DDS, MSc, Graduate student, Department of Restorative Dentistry, São Paulo State University, São José dos Campos, SP, Brazil.
3- DDS, MSc, PhD, Adjunct Professor, Department of Restorative Dentistry, São Paulo State University, São José dos Campos, SP, Brazil.

2- DDS, MSc, PhD, Assistant Professor, Department of Oral Diagnosis and Biosciences, São Paulo State University, São José dos Campos, SP, Brazil.

4- DDS, MSc, PhD, Assistant Professor, Department of Restorative Dentistry, São Paulo State University, São José dos Campos, SP, Brazil.

5- DDS, MSc, PhD, Adjunct Professor, Department of Oral Diagnosis and Biosciences, São Paulo State University, São José dos Campos, SP, Brazil.

6- DDS, MSc, PhD, Full Professor, Department of Oral Diagnosis and Biosciences, São Paulo State University, São José dos Campos, SP, Brazil.
\end{abstract}

Corresponding address: Lilian Eiko Maekawa - Evolução, 692 - 04163-001 - São Paulo - SP - Brazil - Phone: +55-11-5058-1693 - +55-11-9958-9908 - Fax: +55-11-5058-1693 - e-mail: lilian.maekawa@uol.com.br

Received: July 01, 2009 - Modification: August 12, 2009 - Accepted: February 16, 2010

\section{ABSTRACT}

$\mathrm{O}$ bjective: The purpose of this study was to evaluate the efficacy of auxiliary chemical substances and intracanal medications on Escherichia coli and its endotoxin in root canals. Material and Methods: Teeth were contaminated with a suspension of E. coli for 14 days and divided into 3 groups according to the auxiliary chemical substance used: G1) $2.5 \%$ sodium hypochlorite ( $\mathrm{NaOCl}$ ); G2) $2 \%$ chlorhexidine gel (CLX); G3) pyrogenfree solution. After, these groups were subdivided according to the intracanal medication (ICM): A) Calcium hydroxide paste (Calen $\AA$ ), B) polymyxin B, and C) Calcium hydroxide paste $+2 \% \mathrm{CLX}$ gel. For the control group (G4), pyrogen-free saline solution was used without application of intracanal medication. Samples of the root canal content were collected immediately after biomechanical preparation (BMP), at 7 days after BMP, after 14 days of intracanal medication activity, and 7 days after removal of intracanal medication. The following aspects were evaluated for all collections: a) antimicrobial activity; b) quantification of endotoxin by the Limulus Amebocyte Lysate test (LAL). Results were analyzed by the Kruskal-Wallis and Dunn's tests at 5\% significance level. Results: The $2.5 \% \mathrm{NaOCl}$ and $\mathrm{CLX}$ were able to eliminate $E$. coli from root canal lumen and reduced the amount of endotoxin compared to saline. Conclusions: It was concluded that $2.5 \% \mathrm{NaOCl}$ and CLX were effective in eliminating $E$. coli. Only the studied intracanal medications were to reduce the amount of endotoxin present in the root canals, regardless of the irrigant used.

Key words: Endotoxins. Sodium hypochlorite. Chlorhexidine. Calcium hydroxide. Polymyxin B.

\section{INTRODUCTION}

The technological improvements in culture and microbiological identification in the 1980s showed predominance of anaerobic bacteria in root canals with necrotic pulp and chronic periapical lesion, especially Gram-negative microorganisms ${ }^{9,13,27}$. These bacteria contains endotoxins on their cellular wall, which are released during duplication or cell death and are composed of polysaccharides, lipids and proteins ${ }^{9}$, also known as lipopolysaccharides (LPS). The $A$ lipid is the molecular region of the endotoxin responsible for its toxic effect ${ }^{16}$.

In the blood and tissues, the endotoxins bind to the CD-14 receptor on the surface of monocytes/ macrophages and these cells, once activated, secret interleukins (IL- $1 \alpha$, IL-1 $\beta$, IL- 6, IL- 8$)^{12}$ and a-tumor necrosis factor $(\mathrm{TNF}-\alpha)^{1}$. The endotoxins can even increase the release of neurotransmitters and vasoactive substances at the periapical tissues and nerve-ending regions, causing pain ${ }^{27}$, and stimulate the host cells to release the E2-prostaglandin ${ }^{23}$, which has influence on the osteoclasts, perpetuating the periapical inflammatory reaction. Besides, the endotoxin can diffuse through the dentinal tubules 
towards the cement in $24 \mathrm{~h}^{18}$

An important correlation between the endotoxin levels and the clinical symptomatology of the pulp and periapical tissues has been demonstrated 7,26 , suggesting that endotoxins are one of the main etiological factors involved with pulpal and periapical pathologies $8,13,22$.

During biomechanical preparation (BMP), several chemical substances have been used as irrigants. Due to a series of properties, sodium hypochlorite is today the most used during root canal instrumentation and irrigation ${ }^{14,33}$. The $2 \%$ chlorhexidine has also been used due to its antimicrobial effect, residual action and biocompatibility ${ }^{11,28,34}$. Although sodium hypochlorite $(\mathrm{NaOCl})$ and $\mathrm{CHX}$ are commonly used in endodontics, the efficacy of these substances has not been observed on endotoxins during the biomechanical root canal preparation ${ }^{2,19,29,33}$. However, despite the antimicrobial effect of the chemical substances auxiliary to the BMP, some microorganisms and endotoxins can remain in the root canal system, dentinal tubules and apical resorption craters, requiring the use of intracanal medication.

Calcium hydroxide has been widely used as intracanal medicament due to its antimicrobial properties $^{14,32}$ and capacity to induce mineralization ${ }^{10}$ and has been proven effective action on endotoxins ${ }^{9,17,20,30}$.

The polymyxin $B$ is a cationic antibiotic that act in the permeability cellular walls of Gramnegatives bacteria, causing bacteria death. Beyond the antimicrobial activity the polymyxin $B$ is able to neutralize endotoxins, blocking some biologic effects caused by these ${ }^{5,15}$.

This study evaluated of the BMP using $\mathrm{NaOCl}$ or chlorhexidine associated with calcium hydroxide, calcium hydroxide plus $2 \%$ chlorhexidine gel or polymyxin B on Escherichia coli and to quantify the endotoxins in root canals after use of these procedures.

\section{MATERIAL AND METHODS}

The present study was approved by the Research Ethics Committee of the São Paulo State University, São José dos Campos Dental School, Brazil (protocol n.067/2005). One hundred and twenty recently extracted human single-rooted teeth were used. They remained immersed in pyrogen-free saline solution (saline) (Aster Produtos Médicos Ltda., Sorocaba, SP, Brazil) prior to use. The crowns were crosscut with a carborundum disc and the length of the specimen was established at $16 \pm 0.5$ $\mathrm{mm}$. Initial root canal instrumentation was done up to $\mathrm{K}$ file \#30 (Dentsply Maillefer, Petrópolis, $\mathrm{RJ}, \mathrm{Brazil})$, and the canals were irrigated with $1 \%$ $\mathrm{NaOCl}$ solution at each change of instrument. After biomechanical preparation, the canals were dried and filled with EDTA (Inodon, Porto Alegre, RS, Brazil) for $3 \mathrm{~min}$ and irrigated with $10 \mathrm{~mL}$ of saline. Next, the apical region of teeth was sealed with light-cured composite resin (Z-100. 3M, Sumaré, $S P$, Brazil) and the outer surfaces of the roots were rendered waterproof with an epoxy adhesive layer, except for the cervical opening region. These teeth were distributed randomly, according to anatomy to standardize the groups. The roots were joined to clear light-cured acrylic resin (Dencor Artigos Odontológicos Classico, São Paulo, SP, Brazil) in 24-well plates with (Costar, New York, NY, USA). The plates, instruments and materials used were sterilized by gamut radiation with cobalt 60 (20 KGy for $6 \mathrm{~h}$ ) in order to neutralize the pre-existing endotoxins 4 .

Escherichia coli (ATCC 25922) suspension in sterile and pyrogen-free saline solution containing $10^{6}$ cells $/ \mathrm{mL}$ was prepared, the root canals were contaminated with $10 \mu \mathrm{L}$ of this suspension and with $10 \mu \mathrm{L}$ of $\mathrm{BHI}$ broth and a pyrogen-free pellet soaked with $\mathrm{BHI}$ was placed in the root canal opening. After contamination, the specimens were stored at $37^{\circ} \mathrm{C}$ in relative humidity for 14 days and at each 3-day period the $\mathrm{BHI}$ broth was added to the root canals ${ }^{14}$. After the contamination period, collections were made of all specimens to confirm the root canal contamination (confirmation collection).

After confirmation, the specimens were divided into 3 experimental groups $(n=36)$, according to the irrigant used: group 1: $2.5 \% \mathrm{NaOCl}$ (Terapêutica Farmácia de Manipulação, São José dos Campos, SP, Brazil); group 2: 2\% chlorhexidine gel $[2 \%$ chlorhexidine in $0.8 \%$ natrosol gel (CLX) (Byoformula Farmácia de Manipulação, São José dos Campos, SP, Brazil)]; group 3 and group 4 (control): saline.

Biomechanical preparation was made with 1-mm retreat to $\mathrm{K}$ file \#50 and step-back preparation up to $\mathrm{K}$ file $\# 80$. In groups 1,3 and $4,3 \mathrm{~mL}$ of irrigant were used at each change of instrument. In group $2,2 \% \mathrm{CLX}$ gel was placed inside the root canals to the top, the canals were instrumented and irrigated with $3 \mathrm{~mL}$ of saline; this procedure was done at each change of instrument.

After preparation, two collections were made from the root canal: one immediately after instrumentation ( $1^{\text {st }}$ collection) and another 7 days later ( $2^{\text {nd }}$ collection). The roots remained in saline and a pyrogen-free pellet in the root canal opening between the $1^{\text {st }}$ and $2^{\text {nd }}$ collections.

Next, groups 1, 2 and 3 were subdivided into 3 groups $(n=12)$, according to the intracanal medication applied: A) calcium hydroxide paste (CHP) (Calen ${ }^{\circledR}$, S.S. White, Rio de Janeiro, RJ, Brazil); B) polymyxin B solution (PmB) $(10,000 \mathrm{IU} / \mathrm{mL})$ (Ophtalmos Fórmulas Oficiais, 
São Paulo, SP, Brazil); C) pro-analysis calcium hydroxide association (P.A.) (Biodinâmica Química e Farmacêutica Ltda., Ibiporã, PR, Brazil) with $2 \%$ CLX gel (CHP + 2\% CLX gel) (Byoformula Farmácia de Manipulação). The ratio was $1: 1$, the consistency of the paste was similar to a toothpaste. In the group 4 (control group) $(n=12)$, biomechanical preparation was made only with the saline and the intracanal medication was not used; the canals were kept with saline. Before placement of the intracanal medication, EDTA was used for 3 min followed by root canal irrigation with $10 \mathrm{~mL}$ of saline to cleaning of the root canals walls and better diffusion of intracanal medication.

After application of intracanal medication, the roots remained in an oven at $37^{\circ} \mathrm{C}$ for 14 days. After that period, the medication was removed and the root canal contents were collected ( $3^{\text {rd }}$ collection). The canals were filled with saline and after 7 days another collection was carried out ( $4^{\text {th }}$ collection: 7 days after removal of intracanal medication).

All collections in root canals (confirmation; $1^{\text {st }}$ collection: immediately after instrumentation; $2^{\text {nd }}$ collection: 7 days after biomechanical preparation; $3^{\text {rd }}$ collection after medication maintenance for 14 days; $4^{\text {th }}$ collection: 7 days after removal of intracanal medication) were made in the same manner: the canals were filled with saline and $100 \mu \mathrm{L}$ of the content were collected from the root canal with $1 \mathrm{~mL}$ syringes for microbiological and endotoxin count analysis.

To determine the antimicrobial activity of the auxiliary chemical substances and intracanal medications used, serial dilutions were made with samples double collected from the root canal and plated on plates containing BHI agar. Then, they were incubated in an oven at $37^{\circ} \mathrm{C}$ for $48 \mathrm{~h}$ and after that the counts of colony forming units (CFU/ $\mathrm{mL}$ ) of $E$. coli were performed.

In order to check the endotoxin neutralization, the chromogenic kinetic method of the Limulus amebocyte lysate test (LAL) (Cambrex, São Paulo, SP, Brazil) was used. A kinetic reader QCL (Cambrex) was used, connected to a computer with a Wink QCL software (Cambrex) specific for management, accomplishment and report writing. LAL test is the most considerable and trustworthy method for detention of endotoxin, allowing to quantify the endotoxin with higher precision. The curve-standard (concentrations between 0.005 and $50 \mathrm{EU} / \mathrm{mL}$ ) was done according to fabricant. This software automatically calculates the parameters of the standard curve, and the values of the samples in endotoxin units $(\mathrm{EU} / \mathrm{mL})$.

All data were analyzed by the Kruskal-Wallis and Dunn's test at 5\% significance level. Statistical analysis was carried out according to the collections made during the study: $1^{\text {st }}$ collection, $2^{\text {nd }}$ collection, $3^{\text {rd }}$ collection and $4^{\text {th }}$ collection.

The $1^{\text {st }}$ and $2^{\text {nd }}$ collections were analyzed comparing the auxiliary chemical substance used, whereas for the $3^{\text {rd }}$ and $4^{\text {th }}$ collections the groups were analyzed individually between themselves.

\section{RESULTS}

The microbiological analysis revealed that, upon the confirmation collection, there was microbial growth of all specimens; after biomechanical preparation with $2.5 \% \mathrm{NaOCl}$ and $2 \% \mathrm{CLX}$ gel the number of bacteria went under the detection limit. After application of the intracanal medication, the

Table 1- Mean of colony forming units/ milliliter (CFU/mL) in groups

\begin{tabular}{|c|c|c|c|c|c|c|}
\hline $\begin{array}{l}\text { Irrigation } \\
\text { solution }\end{array}$ & $\begin{array}{c}\text { Confirmation } \\
\text { collection } \\
\text { CFU/mL }\end{array}$ & $\begin{array}{c}1^{\text {st }} \\
\text { collection } \\
\text { CFU/mL }\end{array}$ & $\begin{array}{c}2^{\text {nd }} \\
\text { collection } \\
\text { CFU/mL } \\
\end{array}$ & $\begin{array}{c}\text { Intracanal } \\
\text { medication } \\
\text { CFU/mL }\end{array}$ & $\begin{array}{c}3^{\text {rd }} \\
\text { collection } \\
\text { CFU/mL } \\
\end{array}$ & $\begin{array}{c}4^{\text {th }} \text { collection } \\
\text { CFU/mL }\end{array}$ \\
\hline & & & & $\mathrm{A}\left(\mathrm{Ca}(\mathrm{OH})_{2}\right)$ & 0 & 0 \\
\hline \multirow[t]{3}{*}{$2.5 \% \mathrm{NaOCl}$} & $9.06 \times 10^{8}$ & 0 & 0 & $\mathrm{~B}(\mathrm{PmB})$ & 0 & 0 \\
\hline & & & & $\mathrm{C}\left(\mathrm{Ca}(\mathrm{OH})_{2}+\mathrm{CLX}\right)$ & 0 & 0 \\
\hline & & & & $\mathrm{A}\left(\mathrm{Ca}(\mathrm{OH})_{2}\right)$ & 0 & 0 \\
\hline \multirow[t]{3}{*}{ CLX } & $2.22 \times 10^{8}$ & 0 & 0 & $\mathrm{~B}(\mathrm{PmB})$ & 0 & 0 \\
\hline & & & & $\mathrm{C}\left(\mathrm{Ca}(\mathrm{OH})_{2}+\mathrm{CLX}\right)$ & 0 & 0 \\
\hline & & & & $\mathrm{A}\left(\mathrm{Ca}(\mathrm{OH})_{2}\right)$ & 0 & 0 \\
\hline \multirow{2}{*}{$\begin{array}{l}\text { Pyrogen-free } \\
\text { saline solution }\end{array}$} & $3.08 \times 10^{8}$ & $1 \times 10^{5}$ & $4.4 \times 10^{6}$ & $\mathrm{~B}(\mathrm{PmB})$ & 0 & 0 \\
\hline & & & & $\mathrm{C}\left(\mathrm{Ca}(\mathrm{OH})_{2}+\mathrm{CLX}\right)$ & 0 & 0 \\
\hline $\begin{array}{l}\text { Pyrogen-free } \\
\text { saline solution }\end{array}$ & $3.31 \times 10^{8}$ & $6 \times 10^{4}$ & $4.2 \times 10^{6}$ & $\begin{array}{c}\text { Pyrogen-free saline } \\
\text { solution }\end{array}$ & $5.5 \times 10^{4}$ & $2 \times 10^{5}$ \\
\hline
\end{tabular}

$\mathrm{CLX}=$ chlorhexidine; $\mathrm{PmB}=$ polymyxin $\mathrm{B} ; \mathrm{CHP}=$ calcium hydroxide paste. 
values of UFC/mL remained equal to zero, therefore there was no need to apply the statistical test to those results (Table 1 ).

In group 3 (pyrogen-free saline solution), there was microorganism reduction regarding the confirmation collection in all specimens. It was observed that, on the $2^{\text {nd }}$ collection ( 7 days after the BMP), there was an increase in the number of microorganisms. It was also noted that, after application of intracanal medication, the number of bacteria went under the detection limit. However, in group 4 (control), in which no intracanal medication was used, the microorganisms remained viable throughout the study period.

Table 2 presents the values obtained in the quantification of endotoxins. It was observed that, on the $1^{\text {st }}$ and $2^{\text {nd }}$ collections, $\mathrm{NaOCl}$ and $\mathrm{CLX}$ were similar to each other $(p>0.05)$ and different from pyrogen-free saline solution $(p<0.05)$. The median obtained on the counting of $\mathrm{EU} / \mathrm{mL}$, as well as the homogeneous groups after the $3^{\text {rd }}$ and $4^{\text {th }}$ collections are displayed in Table 3.

On the $3^{\text {rd }}$ collection, immediately after intracanal medication, it was noted that groups $G 1 A, G 1 B$, G1C, G2A, G2C, G3A, G3C were significantly different from the control group $G 4(p<0.05)$. The groups G1C, G2A, G2C and G3C presented the lowest endotoxin values, being equal to groups G1A, G1B, G3A and G3B ( $p>0.05)$. Even though groups $\mathrm{G} 2 \mathrm{~B}$ and $\mathrm{G} 3 \mathrm{~B}$, which used the polymyxin $\mathrm{B}$ as intracanal medication, reduced the amount of endotoxin in the root canals, it was not enough to indicate statistically significant difference compared with the control group (G4) ( $p>0.05)$. However, group $\mathrm{G} 2 \mathrm{~B}$ was equal to groups $\mathrm{G} 1 \mathrm{~A}, \mathrm{G} 1 \mathrm{~B}$ and $\mathrm{G} 3 \mathrm{~A}$, and the $G 3 B$ was equal to the others $(p>0.05)$.

Upon the $4^{\text {th }}$ collection, a statistically significant difference was also noted between groups. The

Table 2- Descriptive statistics of the median and homogeneous groups of quantity of endotoxin of $E$. coli $(E U / \mathrm{mL})$ on the first and second collections

\begin{tabular}{|c|c|c|c|c|}
\hline \multirow[t]{2}{*}{ Irrigation solution } & \multicolumn{2}{|c|}{$\begin{array}{c}1^{\text {st }} \text { collection } \\
\mathrm{EU} / \mathrm{mL}\end{array}$} & \multicolumn{2}{|c|}{$\begin{array}{c}2^{\text {nd }} \text { collection } \\
\mathrm{EU} / \mathrm{mL}\end{array}$} \\
\hline & Median & $\begin{array}{c}\text { Homogeneous } \\
\text { groups* }\end{array}$ & Median & $\begin{array}{c}\text { Homogeneous } \\
\text { groups* }\end{array}$ \\
\hline $\mathrm{NaOCl} 2.5 \%$ & 118.5 & $\mathrm{~B}$ & 563 & $\bar{B}$ \\
\hline $2 \%$ CLX gel & 104.9 & B & 227 & B \\
\hline $\begin{array}{l}\text { Pyrogen-free } \\
\text { saline solution }\end{array}$ & 444 & $A$ & 6940 & A \\
\hline
\end{tabular}

*different letters indicate statistically significant difference $(p<0.05)$

Table 3- Descriptive statistics of the median and homogeneous groups of quantity of endotoxin of $E$. coli (EU/mL) on the third and fourth collections

\begin{tabular}{cccccc}
\hline Irrigation solution & $\begin{array}{c}\text { Intracanal } \\
\text { medication }\end{array}$ & \multicolumn{2}{c}{$\begin{array}{c}3^{\text {rd }} \text { collection } \\
\mathrm{EU} / \mathrm{mL}\end{array}$} & $\begin{array}{c}\text { 4 }^{\text {th }} \text { collection } \\
\mathrm{EU} / \mathrm{mL}\end{array}$ \\
\hline & & Median & $\begin{array}{c}\text { Homogeneous } \\
\text { groups }^{*}\end{array}$ & Median & $\begin{array}{c}\text { Homogeneuos } \\
\text { groups }^{*}\end{array}$ \\
$\mathrm{G} 1$ & $\mathrm{~A}\left(\mathrm{Ca}(\mathrm{OH})_{2}\right)$ & 14.25 & $\mathrm{BC}$ & 12.5 & $\mathrm{BC}$ \\
$\mathrm{NaOCl} 2.5 \%$ & $\mathrm{~B}(\mathrm{PmB})$ & 19.45 & $\mathrm{BC}$ & 9.58 & $\mathrm{C}$ \\
& $\mathrm{C}\left(\mathrm{Ca}(\mathrm{OH})_{2}+\mathrm{CLX}\right)$ & 4.05 & $\mathrm{C}$ & 23.9 & $\mathrm{BC}$ \\
$\mathrm{G} 2$ & $\mathrm{~A}\left(\mathrm{Ca}(\mathrm{OH})_{2}\right)$ & 7.19 & $\mathrm{C}$ & 16.9 & $\mathrm{BC}$ \\
$2 \% \mathrm{CLX}$ gel & $\mathrm{B}(\mathrm{PmB})$ & 176 & $\mathrm{AB}$ & 67.5 & $\mathrm{ABC}$ \\
& $\mathrm{C}\left(\mathrm{Ca}(\mathrm{OH})_{2}+\mathrm{CLX}\right)$ & 11.35 & $\mathrm{C}$ & 17.2 & $\mathrm{BC}$ \\
G3 & $\mathrm{A}\left(\mathrm{Ca}(\mathrm{OH})_{2}\right)$ & 12.8 & $\mathrm{BC}$ & 95.3 & $\mathrm{AB}$ \\
Pyrogen-free & $\mathrm{B}(\mathrm{PmB})$ & 37.5 & $\mathrm{ABC}$ & 33.2 & $\mathrm{BC}$ \\
saline solution & $\mathrm{C}\left(\mathrm{Ca}(\mathrm{OH})_{2}+\mathrm{CLX}\right)$ & 8.87 & $\mathrm{C}$ & 13.37 & $\mathrm{BC}$ \\
G4 & $\mathrm{Pyrogen}-\mathrm{free}$ & 2160 & $\mathrm{~A}$ & 2790 & $\mathrm{~A}$ \\
Pyrogen-free & saline solution & & & & \\
saline solution & & & & & \\
\hline
\end{tabular}

*different letters indicate statistically significant difference $(p<0.05)$ 
G1B presented lower endotoxin value but was statistically equal to groups G1A, G1C, G2A, G2B, G2C, G3B and G3C ( $p>0.05$ ). The groups $G 2 B$ and G3A exhibited reduced the amount of endotoxin in the root canals, yet it was not enough to indicate statistically significant difference in relation to group 4 (control). The other groups G1A, G1B, G1C, G2A, G2C, G3B, G3C presented considerable reduction of endotoxins compared to the control group G4 $(p<0.05)$.

\section{DISCUSSION}

Even though the Escherichia coli is not commonly found in root canals with necrotic pulp, some studies found $E$. coli in root canals with periapical lesions ${ }^{6,31}$. Its endotoxin presents the basic structure of the lipid component, which represents the active center responsible for the toxicity of LPS.

Upon microbiological analysis after the biomechanical preparation ( $1^{\text {st }}$ collection), it was seen that in the group irrigated with saline solution there was microorganism reduction compared with the confirmation collection. However, in groups instrumented with $\mathrm{NaOCl}$ and $2 \% \mathrm{CLX}$ gel, the number of bacteria went under the detection limit. Even after 7 days of biomechanical preparation, with the canal filled with pyrogen-free saline solution, there was no bacterial growth confirming that the $2.5 \% \mathrm{NaOCl}$ and the $2 \% \mathrm{CLX}$ gel eliminated the $E$. coli in the root canal lumen. Orstavik and Haapasalo ${ }^{21}$ (1990) verified that $E$. coli penetrates much less into the dentinal tubules than other species. It may count to its susceptibility to the irrigants agents used in this study.

In the present study, in the group instrumented with saline solution, only microorganism reduction was noted. This reduction was due to the physical (abundant irrigation and effective aspiration) and mechanical (root canal instrumentation) means, since the saline solution does not present antimicrobial activity. These results agree with those of Byström \& Sundqvist ${ }^{3}$ (1983), which showed that saline is ineffective.

The results obtained from this study when $2 \%$ CLX gel was used as auxiliary substance to the biomechanical preparation complied with other studies that used $2 \%$ CLX gel as chemical substance auxiliary to biomechanical preparation and showed the effectiveness of this substance on the microorganisms present in the root canal ${ }^{25}$.

Even though the chemical substances used in biomechanical preparation have shown antimicrobial activity on $E$. coli, they were not able to eliminate the endotoxins present in the root canal. On the $1^{\text {st }}$ collection, it was seen that $2.5 \% \mathrm{NaOCl}$ and $2 \%$ CLX gel showed lower amounts of endotoxin when compared with the control group where only the pyrogen-free saline solution was used as irrigant auxiliary to root canal instrumentation. These results comply with other studies that also observed that biomechanical preparation with $\mathrm{NaOCl}$ and $2 \%$ CLX gel is not enough to inactivate the endotoxin ${ }^{19}$, requiring the complementary action of intracanal medications. It was also seen that, after 7 days ( $2^{\text {nd }}$ collection), the amount of endotoxins was higher than the $1^{\text {st }}$ collection. It shows that the biomechanical preparation with $\mathrm{NaOCl}$ or CLX, even eliminating the $E$. coli in the root canals, left the endotoxins released with bacterial death remain in the dentinal smear layer, requiring the use of intracanal medication in order to inactivate these endotoxins.

After the use of intracanal medication, the results showed considerable reduction of endotoxin with all medications tested when compared with the $2^{\text {nd }}$ collection. In some specimens the calcium hydroxide paste and the association of calcium hydroxide and the $2 \%$ CLX gel were able to inactivate the endotoxins. The polymyxin $B$ reduced the endotoxin count, yet it was not able to inactivate them completely in any specimen and did not differ from the control group upon the $3^{\text {rd }}$ and $4^{\text {th }}$ collections in groups irrigated with CLX and on the $3^{\text {rd }}$ collection in the group irrigated with PFS. Similar results were found by Tanomaru, et al. ${ }^{33}$ (2003), who used a similar methodology and reported that biomechanical preparation with $\mathrm{NaOCl}$ and CLX solutions could not inactivate the effects of endotoxins; however, the calcium hydroxide inactivated the effects of endotoxins.

In vitro studies have already shown that calcium hydroxide can inactivate the endotoxins. Safavi and Nichols ${ }^{24}$ (1993) saw that calcium hydroxide hydrolyzes the $A$ lipids resulting in high release of free fatty acids. In 1994 these authors identified ${ }^{23}$ the E2 prostaglandin production in floating monocytes stimulated by the LPS; however, the E2 prostaglandins were not identified in floating elements that were previously treated with calcium hydroxide. Yet, Nelson-Filho, et al. ${ }^{17}$ (2002) and Silva, et al. ${ }^{30}$ (2002) observed in dog's teeth that the endotoxin caused radiographically and histopathologically visible periapical lesion, yet when associated with calcium hydroxide that endotoxin lost its toxic action.

In the present study, it was seen that the only intracanal medication that differed from the control in all groups was CHP+CLX (groups G1C, G2C and $\mathrm{G} 3 \mathrm{C}$ ). The calcium hydroxide associated with CLX was able to neutralize endotoxins due to its calcium hydroxide action. Besides, that association brings together the antimicrobial properties of CLX and the mineralization potential and neutralization of endotoxins by calcium hydroxide.

As for the effectiveness of polymyxin $B$, it was 
seen that groups G2B (BMP: CLX; MIC: PmB) and G3B (BMP: PFS; MIC PmB) were equal to the control group on the $3^{\text {rd }}$ and $4^{\text {th }}$ collections and $3^{\text {rd }}$ collection, respectively. It shows that polymyxin in these groups was not able to considerably reduce the amount of endotoxins. These results can be explained by the fact that polymyxin B is an antibiotic, since Oliveira, et al. ${ }^{19}$ (2007) saw the effective neutralization of the endotoxin after biomechanical preparation with polymyxin B. However, Oliveira, et al. ${ }^{20}$ (2005), when using polymyxin $B$ as intracanal medication for 7 days, noted a reduction in endotoxin counts. That difference between polymyxin $B$ action as irrigant and as intracanal medication occurs because polymyxin $\mathrm{B}$ is an antibiotic with immediate local action, losing its effectiveness after some $h$ in the root canal. Morrison and Jacobs ${ }^{15}$ (1976) found that polymyxin $B$ has the capacity to bind with high affinity to an A lipid portion, thus altering the tridimensional conformation of the LPS molecule. This conformational alteration possibly restrains the complex endotoxin-polymyxin B from binding to the CD14 receptor in the monocytes, inhibiting the release of inflammatory mediators 5 .

\section{CONCLUSION}

Root canal biomechanical preparation with $2.5 \% \mathrm{NaOCl}$ and $2 \% \mathrm{CLX}$ gel as auxiliary chemical substances promoted the elimination of $E$. coli in the root canal lumen and considerably reduced the amount of endotoxin compared to saline. Only the intracanal medications were able to reduce the amount of endotoxin present in the root canals, regardless the irrigant used during biomechanical preparation.

\section{REFERENCES}

1- Barthel CR, Levin LG, Reisner HM, Trope M. TNF-alpha release in monocytes after exposure to calcium hydroxide treated Escherichia coli LPS. Int Endod J. 1997;30:155-9.

2- Buttler TK, Crawford JJ. The detoxifying effect of varying concentrations of sodium hypochlorite on endotoxins. J Endod. 1982;8:59-66.

3- Byström A, Sundqvist G. Bacteriologic evaluation of the effect of 0.5 percent sodium hypochlorite in endodontic therapy. Oral Surg Oral Med Oral Pathol. 1983;55:307-12.

4- Csako G, Elin RJ, Hochstein D, Tsai CH. Physical and biological properties of U.S. standard endotoxin EC after exposure to ionizing radiation. Infect Immun. 1983;41:190-6.

5- Evans ME, Feola DJ, Rapp RP. Polymyxin B sulfate and colistin: old antibiotics for emerging multiresistant gram-negative bacteria. Ann Pharmacother. 1999;33:960-7.

6- Geibel MA, Schu B, Callaway AS, Gleissner C, Willershansen B. Polymerase chain reaction-based simultaneous detection of selected bacterial species associated with closed periapical lesions. Eur J Med Res. 2005;10:333-8.

7- Horiba N, Maekawa Y, Abe Y, Ito M, Matsumoto T, Nakamura $\mathrm{H}$. Correlations between endotoxin and clinical symptoms or radiolucent areas in infected root canals. Oral Surg Oral Med Oral Pathol. 1991:71:492-5.
8- Jacinto RC, Gomes BP, Shah HN, Ferraz CC, Zaia AA, SouzaFilho FJ. Quantification of endotoxins in necrotic root canals from symptomatic and asymptomatic teeth. J Med Microbiol. 2005;54:777-83.

9- Leonardo MR, Silva LA, Assed S, Nelson-Filho P. Importance of bacterial endotoxin (LPS) in Endodontics. J Appl Oral Sci. 2004;12:93-8.

10- Leonardo MR, Silveira FF, Silva LA, Tanomaru Filho M, Utrilla LS. Calcium hydroxide root canal dressing. Histopathological evaluation of periapical repair at different time periods. Braz Dent J. 2002,13:17-22

11- Leonardo MR, Tanomaru Filho M, Silva LAB, Nelson Filho $\mathrm{P}$, Bonifácio $\mathrm{KC}$, Ito IY. In vivo antimicrobial activity of $2 \%$ chlorhexidine used as a root canal irrigating solution. J Endod. 1999;25:167-71.

12- Matsushita K, Tajima T, Tomita K, Takada H, Nagaoka S, Torii M. Inflammatory cytokine production and specific antibody responses to lipopolysaccharide from endodontopathic black-pigmented bacteria in patients with multilesional periapical periodontitis. J Endod. 1999:25:795-9.

13- Mattison GD, Haddix JE, Kehoe JC, Progulske-Fox A. The effect of Eikenella corrodens endotoxin on periapical bone. J Endod. 1987;13:559-65.

14- Menezes MM, Valera MC, Koga-Ito CY, Camargo $\mathrm{CH}$, Mancini $\mathrm{MN}$. In vitro evaluation of the effectiveness of irrigants and intracanal medicaments on microorganisms within root canals. Int Endod J. 2004;37:311-9.

15- Morrison DC, Jacobs DM. Binding of polymyxin B to the lipid A portion of bacterial lipopolysaccharide. Immunochemistry. 1976;13:813-8.

16- Morrison DC, Kline LF. Activation of the classical and properdin pathways of complement by bacterial lipopolysaccharides (LPS). J Immun. 1977;118:362-8.

17- Nelson Filho P, Leonardo MR, Silva LA, Assed S. Radiographic evaluation of the effect of endotoxin (LPS) plus calcium hydroxide on apical and periapical tissues of dogs. J Endod. 2002;28:694-6. 18- Oliveira LD, Carvalho CA, Valera MC, Koga-Ito CY, Jorge AO. Diffusion ability of endotoxin through dentinal tubules. Braz Oral Res. 2005:19:5-10.

19- Oliveira LD, Jorge AO, Carvalho CA, Koga-Ito CY, Valera MC. In vitro effects of endodontic irrigants on endotoxins in root canals. Oral Surg Oral Med Oral Pathol Oral Radiol Endod. 2007; 104:135-42.

20- Oliveira LD, Leão MV, Carvalho CA, Camargo CH, Valera MC, Jorge $\mathrm{AO}$, et al. In vitro effects of calcium hydroxide and polymyxin $B$ on endotoxins in root canals. J Dent. 2005;33:107-14.

21- Orstavik D, Haapasalo MP. Disinfection by endodontic irrigants and dressings of experimentally infected dentinal tubules. Endod Dent Traumatol. 1990;6:142-9.

22- Pitts DL, Williams BL, Morton TH Jr. Investigation of the role of endotoxin in periapical inflammation. J Endod. 1982;8:10-8.

23- Safavi KE, Nichols FC. Alteration of biological properties of bacterial lipopolysaccharide by calcium hydroxide treatment. J Endod. 1994:20:127-9.

24- Safavi KE, Nichols FC. Effect of calcium hydroxide on bacterial lipopolysaccharide. J Endod.1993;19:76-8.

25- Sassone LM, Fidel RA, Murad CF, Fidel SR, Hirata R Jr. Antimicrobial activity of sodium hypochlorite and chlorhexidine by two different tests. Austr Endod J. 2008;34:19-24.

26- Schein B, Schilder H. Endotoxin content in endodontically involved teeth. J Endod. 1975;1:19-21.

27- Seltzer S, Farber PA. Microbiologic factors in endodontology. Oral Surg Oral Med Oral Pathol. 1994;78:634-45.

28- Semenoff TA, Semenoff Segundo A, Figueiredo JA. Biocompatibility of different intracanal medications in rat buccal submucosa tissue. ] Appl Oral Sci. 2008;16:12-7.

29- Silva LA, Leonardo MR, Assed S, Tanomaru Filho M. Histological study of the effect of some irrigating solutions on bacterial endotoxin in dogs. Braz Dent J. 2004;15:109-114. 
30- Silva LA, Nelson Filho P, Leonardo MR, Rossi MA, Pansani CA. Effect of calcium hydroxide on bacterial endotoxin in vivo. J Endod. 2002;28:94-8.

31- Siqueira JF Jr, Rôças IN, Souto R, Uzeda M, Colombo AP. Microbiological evaluation of acute periradicular abscesses by DNA-DNA hybridization. Oral Surg Oral Med Oral Pathol Oral Radiol Endod. 2001;92:451-7.

32- Siqueira JF Jr, Uzeda M. Disinfection by calcium hydroxide pastes of dentinal tubules infected with two obligate and one facultative anaerobic bacteria. J Endod. 1996;22:674-6.

33- Tanomaru JM, Leonardo MR, Tanomaru Filho M, Bonetti Filho I, Silva LA. Effect of different irrigation solutions and calcium hydroxide on bacterial LPS. Int Endod J. 2003;36:733-9.

34- Weber CD, McClanahan SB, Miller GA, Diener-West M, Johnson JD. The effect of passive ultrasonic activation of $2 \%$ chlorhexidine or $5.25 \%$ sodium hypochlorite irrigant on residual antimicrobial activity in root canals. J Endod. 2003;29:562-4. 